\title{
Luís Bernardo Honwana, imobilidade e violência sob o olhar infantil
}

Luís Bernardo Honwana, immobility and violence in the perspective of children

$\underline{\underline{\text { Marana Borges }}}$

1 Formada em Jornalismo pela Universidade de São Paulo, mestre em Teoria da Literatura pela Universidade de Lisboa e doutoranda pela mesma instituição. Atualmente é pesquisadora residente no Centre National de la Recherche Scientifique (CNRS), em Paris. 
RESENHA: HONWANA, Luís Bernardo. Nós matamos o cão tinhoso! Série Vozes da África. São Paulo: Kapulana, 2017.

RESUMO: O livro de contos Nós matamos o Cão Tinhoso!, de Luís Bernardo Honwana, publicado em 1964, foi um marco na literatura contemporânea de Moçambique. Nesta resenha, analiso a segunda edição brasileira da obra, que inclui mais um conto ("Rosita, até morrer"). Proponho uma leitura dos contos que leve em consideração o olhar infantil sobre a violência e o consequente desconcerto causado no leitor. A impossibilidade de dar sentido à violência impede os personagens de se rebelarem contra o arbítrio colonial.

PALAVRAS-CHAVE: Honwana; Nós matamos o Cão Tinhoso!; colonialismo; literatura moçambicana; Rosita.

ABSTRACT: The short stories collection We killed Mangy Dog and other Mozambique stories (1964), by Luís Bernardo Honwana, was a turning point in contemporary Mozambican literature. In this review, I analyse the second edition published in Brazil, which includes an extra short story called "Rosita, until death". I consider the children view of violence and its consequent bewilderment caused in the reader. I also argue that the impossibility to provide meaning to the violence prevents the characters from rising against colonial authority.

KEYWORDS: Honwana; We killed Mangy Dog and other Mozambique stories; colonialism; Mozambican literature; Rosita. 
Nós matamos o cão tinhoso! É assim o título do livro que consagrou o moçambicano Luís Bernardo Honwana aos vinte e dois anos. Moçambique era colônia e Honwana, um militante da FRELIMO (Frente pela Libertação de Moçambique). Estávamos em 1964, o mesmo ano em que se iniciaria a luta anticolonial e em que o jovem escritor seria preso por suas atividades políticas. A única obra de ficção de Honwana foi um marco na sociedade intelectual de Moçambique e de vários outros países africanos. Não somente por ser considerada o segundo livro ficcional da literatura moçambicana - depois de Godido e outros contos (1952), de João Dias: foi eleito um dos cem melhores livros africanos do século XX pela Zimbabwe International Book Fair, elogiado por José Craveirinha e exerceu influência em muitas gerações de escritores. Não é pouca coisa. Ainda assim, permaneceria longe das livrarias e bibliotecas brasileiras, não fosse o esforço da Editora Kapulana em editar pela segunda vez a obra no Brasil. A primeira edição data de $1980 .^{2}$

Os críticos são unânimes em enxergar em Honwana um escritor engajado a denunciar o colonialismo. O leitor deve saber que, se assim o é, Honwana fá-lo do melhor modo: com nuances, elipses, alusões, metáforas - enfim, recursos da boa literatura.

O título do livro é uma sentença. Lá há tudo: o sujeito, o predicado com seu verbo. À primeira leitura, parece um tanto longo, rocambolesco, sobretudo para quem desconhece o adjetivo "tinhoso" e, por isso, tarda a entender o objeto direto da frase. Ou, em outras palavras, a vítima: um cão sarnento.

O título é uma denúncia. Ficamos a saber que o cão está morto. Atenção: não é morte morrida, mas morte matada. É assassinato. O cão com seus olhos azuis, "a olhar como uma pessoa a pedir qualquer coisa sem querer dizer”, esse cão que atravessa todo o conto sendo evitado pelas pessoas ao mesmo tempo em que as evita - mataram-no.

A ambiguidade do cão oscila de modo a que matá-lo seja ao mesmo tempo um crime e um fator atenuante. Ora, se atirar em um cão, animal indefeso e doméstico por excelência,

2 A obra compôs o quarto volume da coleção “Autores Africanos”, da Editora Ática, idealizada pelo sociólogo, professor e pesquisador brasileiro Fernando Mourão, também criador do CEA - Centro de Estudos Africanos da Universidade de São Paulo. 
é hediondo, a vítima nesse caso é um cão doente e sem dono que arrasta suas chagas pela vila. Sua pele é velha, coberta de cicatrizes, parecia causar repugnância até mesmo em outros cães. Enfim, "um cão feio" (HONWANA, 2017, p. 13). Um pária. Matá-lo é portanto uma questão de higiene e, no limite, de coesão social.

Pior que suas feridas são seus olhos. Olhos que o humanizam. Ao mesmo tempo, tão grandes que metem medo, segundo o menino narrador. Mas não nos deixemos enganar: medo aqui é ver-se refletido. O olhar do cão causa pena, e a pena, culpa. Ninguém gosta de saber-se responsável pela dor alheia, muito menos quando a dor tem o rosto feio: o horror de ver as "moscas a comer-lhe as crostas das feridas" (idem). Quem manda matá-lo e quem obedece sabe: as chagas do cão são culpa de quem não lhe cuida.

O título é uma confissão: o narrador e seus comparsas o mataram. É um assassinato feito em grupo. "É uma coisa de malta, mesmo de malta" (HONWANA, 2017, p. 25). Para a turma de meninos de que faz parte o narrador, o título não nos obriga à empatia: são culpados. Afinal, foram eles, esses meninos, que o mataram. Mas logo se nos aparece à frente outro problema: os assassinos eram apenas crianças.

Por que não desculpar o narrador? Seu corpo de menino está em todas as partes da narração: na facilidade como acredita que o cão era um sobrevivente da bomba atômica no Japão, na vergonha em expressar aos amigos a empatia que sente pelo animal, na simplicidade da linguagem, na repetição de palavras e frases, em como explicita com pormenores aquilo que, para os adultos, já está subentendido. Talvez pudéssemos adicionar que a infância também está na obediência com que a personagem empreende a função que lhe é imposta - matar.

A infância, contudo, não basta para desculpar o crime.

O título é uma acusação: mais que saber da morte de um cão, interessa apontar o dedo. Os culpados sobrepõem-se à vítima. A lista é longa e, quanto mais detalhada, mais cruel e absurda ela se torna; também mais claramente reproduz a hierarquia social: o Senhor Administrador pedira a cabeça do cão; o Duarte da Veterinária foi o encarregado de executá-lo, mas preferiu transferir a outrem o serviço sujo; coagiu as crianças, que cumpriram a tarefa.

O sujeito do título estende-se à toda a comunidade. Em 'nós' cabem muitos nomes, mais do que os citados. Com ponto de exclamação, o título é tiro e lápide: nós matamos! Nele está todo o sistema colonial arbitrário que permite a uma motivação pueril e pessoal provo- 
car um assassinato. Fica-se a saber que o Senhor Administrador, após perder uma partida de cartas, teria passado tanta vergonha em público que, para mostrar seu poder, decidiu mandar matar o cachorro. Vinga-se de seu próprio azar escolhendo um alvo fraco. Em 'nós' também está o adulto que abusa do poder como resposta ao abuso que ele próprio sofreu. É o Doutor que aproveita-se da obediência das crianças para recrutá-las.

O cão está morto, e passaremos o conto a postergar esse momento, incrédulos diante do grupo de meninos que, antes de se lhes nascerem o bigode, já sabem portar uma Ponto 22 de Um Tiro. Honwana prefere mostrar o que alguns leitores preferiam ver como alusão: o grande dia, o tiroteio, a fumaça. A descrição do assassínio é feita com grande pompa, e o desfecho do conto se prolonga ainda mais um pouco, com uma repentina (e talvez por isso pouco convincente) volta à normalidade e à sala de aula.

“Nós matamos o Cão Tinhoso!” é certamente a narrativa mais bem lograda do volume de sete contos, e creio ser acertado buscar nela a unidade da obra. Ali se concentra uma das estratégias mais interessantes do livro: o desconcerto do leitor com o modo como a violência física e psicológica é percebida pelo olhar infantil; desconcerto esse também vivido pelas próprias personagens, que não chegam no entanto a compreender a profunda dimensão social da violência a que se submetem e que reproduzem. Protagonistas e narradores, mesmo quando adultos, compartilham sempre uma postura desarmada, por vezes ingênua, frequentemente poética face à realidade.

A violência não é apenas de socos e espingardas. Em Honwana, até a natureza é violenta - as rolas devoram as plantações de milho; o sol do meio-dia devasta os corpos e turva a vista; a cobra mata um cachorro e esse simples acontecimento poderá arruinar o pai da família. A violência está em todas partes: motivada pela classe, gênero, origem, cor, língua. É opressão social e pobreza. Mostra sua força ao instalar-se no seio das relações familiares. Vamos encontrá-la na descrição exaustiva de uma casa feita no conto "Inventário de imóveis e jacentes", revelando na banalidade de colchões e paredes a claustrofobia e falta de espaço - o que inclui uma definição de 'corredor' tão infantil quanto perfeita: “Acho que por lá passamos sempre que vamos de uma divisão para a outra" (HONWANA, 2017, p. 53).

Como responder à violência? O pai que perde a filha para a prostituição, o trabalhador que perde suas terras férteis para o Estado, a mãe que, para sanar a fome do filho, só pode lhe 
oferecer chá. A resposta à violência é a imobilidade. Junto ao desconcerto do olhar infantil, ela é outro elemento que dá força à escrita de Honwana. Aqui, imobilidade social e de ação vêm juntas. A rebeldia implode nos pulmões, nunca o suficientemente forte para o grito. Gera-se uma tensão que nenhum personagem pode resolver e da qual ninguém consegue escapar.

O insolúvel, penso, tem a ver com o fato de que as personagens sequer conseguem elaborar pela linguagem as razões da violência. Ou, quando o fazem, deparam-se a seguir com algum interdito que lhes impede de fortalecer e partilhar essa linguagem. A violência segue sem ser entendida e, por isso, sem ser desmantelada. Engolem-na. Engolem-na e ensinam a engoli-la. A exemplo de um pai trabalhador que, ameaçado por um português a pagar-lhe uma indenização arbitrária, o insulta em voz alta - mas somente depois do algoz ir embora.

\footnotetext{
- Filho da mãe!

Aproximei-me dele e puxei-lhe a manga do casaco:

- Papá, por que é que não disseste isso à frente dele?

Não me respondeu (HONWANA, 2017, p. 102).
}

Se lembrarmos do título do livro, poderíamos questionar se a imobilidade a que me refiro realmente funciona como elemento estruturador da narração. Afinal, os meninos pegaram em armas e mataram o Cão Tinhoso. Mas fizeram-no a muito custo. Quim, o líder do grupo, ordena repetidas vezes que o narrador seja o primeiro a atirar no cão. Sem sucesso. Depois conta até três e espera uma ação coletiva. Sem sucesso. Com muito esforço, convence os seus colegas, e todos atiram no cão. Há uma tentativa de compreender o absurdo do assassínio: buscam-se justificativas, todas aquelas que respaldem a hierarquia e desresponsabilizem os meninos enquanto autores do crime. No fim das contas, o narrador, a quem lhe chamam de "preto de um raio", não consegue desobedecer. Ele atira no cão, sim, mas sua imobilidade é não reagir ao abuso. A rebeldia permanece latente, e a única coisa que rebenta é a pólvora, a obediência.

Outros exemplos não faltam. O velho Madala, dobrado durante horas sobre o ventre enquanto retira ervas daninhas do chão, é incapaz de queixar-se ou erguer-se, à espera de que o capataz dê sinal para a pausa do almoço. Apenas depois estende "o olhar em volta, sentindo 
um certo prazer em magoar a vista nos pedaços de sol que saltavam das folhas lisas do milho" (“Dina”, p. 62). É o caso também do jovem adulto que volta à casa tremendo, após ser golpeado na rua ${ }^{3}$. A muito custo, tenta explicar à mãe o que lhe aconteceu: “(...) eles bateram-me. (...) $\mathrm{E}$ tudo cai, cai de repente com barulho aqui dentro, e cai e cai e cai..." (HONWANA, 2017, p. 85). A mãe simplesmente não entende. Para sobreviver, não pode entender. Ambos precisam seguir imóveis. Calados: "Ficamos silenciosos os dois, e de tal maneira estávamos abraçados que não sabia se era realmente ela que tremia" (idem).

A língua na qual se poderia elaborar o sentido da violência traz em si a herança do colonizador. Aliás, os contos de Honwana são todos escritos em português, embora integrem termos de outras línguas; são poucos, mas muito significativos se pensarmos no contexto de luta anticolonial: há palavras em ronga e referências à changana (ambas faladas em Moçambique) e à swazi (falada na Suazilândia e África do Sul).

É a impossibilidade de transformar a violência sofrida em verbo - o verbo indica ação e ter essa linguagem partilhada e reconhecida pela comunidade que desembocará em "Rosita, até morrer”. Publicado por primeira vez em Coimbra em 1971, o conto foi incluído na nova edição da Kapulana. Rosita dita a outrem uma carta ao amado que foi embora. A carta está em português, dando indícios de que o amado seria um "assimilado"4. Uma das passagens torna isso mais claro: "Você vai pruguntar as pessoa que anda aqui a falar assim: Ó! Manuel tem esta nossa pele mas agora é branco, comprou ser branco nos papel, esquenceu os vovô dele que

3 Provavelmente eram homens a serviço do Estado colonial português, os chamados cipaios (soldados).

4 Assimilado era todo aquele que aderiu ao Estatuto do Indigenato ou Estatuto do Assimilado, uma formulação política e jurídica do Estado Colonial Português, aplicado em Angola e Moçambique em 1926 (durou até 1961), prevendo um status de “cidadão português” para o autóctone dessas colônias. O Estatuto estabelecia rigorosas exigências e condições ao postulante: renunciar à sua língua materna, à sua cultura, à sua religião e ao seu próprio nome, aderindo ao modo de vida europeu (nome, língua, cultura, educação, religião, vestuário, comportamento etc.). Os assimilados continuaram a ser discriminados racial, social e economicamente e considerados cidadãos de segunda classe. Para quem se interessar pelo assunto, há vasta bibliografia, por exemplo: HERNANDEZ, Leila Maria Gonçalves Leite. A Africa na sala de aula - visita à história contemporânea. 4 ed. São Paulo: Selo Negro, 2012. 
morreu, esquenceu filha dele que nasceu, esquenceu terra, esquenceu tudo" (HONWANA, 2017, p. 140).

A carta escrita por uma pessoa, em nome de outra, é emblemática nos países ou regiões de elevado nível de analfabetismo ${ }^{5}$. Há uma solidariedade por intermédio da escrita e da leitura. Em "Rosita", a carta escrita por alguém que conhecia rudimentos do português, e ditada pela protagonista, coloca em evidência a interdição a um bem cultural e de ascensão social que é a alfabetização e o domínio da língua.

O conto evoca "Mamana Fanisse", de José Craveirinha, em que a protagonista, analfabeta, recebe uma carta e a leva ao português para que ele lhe lesse. Era a notícia da morte de seu marido nas minas da África do Sul, ditas de forma sintética e dura: "Morreu um homem chamado Matolo, lá na mina...” (CRAVEIRINHA, 1997, p. 76).

Em "Rosita", a comunicação vai em sentido contrário: a mulher dita a carta para um tal Chico Mandlate, de quem não sabemos a origem, mas que tem uma atenção maior para com a protagonista do que o português do conto de Craveirinha, indiciando-nos tratar-se de um africano como ela (aliás, o próprio nome o indica). O único português mencionado é Oliveira, proprietário do ônibus. Há uma rede de solidariedade perceptível em torno do convite que Rosa faz ao amado, e que expõe também um mosaico da formação étnica de Moçambique ${ }^{6}$ o motorista do ônibus, Mohano (da cantina; tratar-se-ia de alguém de origem indiana, a julgar pelo nome) e o próprio Chico Mandlate (provavelmente origem machope).

Em ambos os contos, a escrita e a leitura são interditadas às protagonistas e são mediadas pela voz masculina, ora do colonizador, ora talvez de um colonizado. Isso mostra a violência

5 Embora as taxas de analfabetismo não fossem sistematicamente calculadas e divulgadas, estima-se que em 1975, ano da independência, elas eram da ordem de 93\% (fonte: UNESCO Mozambique); daí supor que, à época em que o livro foi publicado, elas fossem ainda maiores. Ver:

https://unesdoc.unesco.org/ark:/48223/pf0000246143_por (consultado em 10.12.2018)

6 A formação étnica e cultural de Moçambique conta com comunidades de bantus, árabes, indianos e europeus, entre outras culturas. Para saber mais, consultar SILIYA, Carlos Jorge. Ensaio sobre a cultura em Moçambique. Maputo: Edição do autor/Cooperação Suíça em Moçambique, 1996. 
simbólica do processo colonial e o alijamento da mulher. Rosita, entretanto, mesmo tendo sido abandonada grávida, não perde a esperança nem o amor: "Sou eu Rosa de teu coração que manda esta carta para teu coração" (HONWANA, 2017, p. 140).

O texto reproduz (e à exaustão) os desvios gramaticais da norma culta portuguesa. Cria uma poética do erro e marca um fosso radical entre a ignorância da língua e os malabarismos para comunicar o amor (e a dor) pela escrita. Esse tratamento da linguagem é ao mesmo tempo político e poético. A língua, somente do avesso, pode dar algum poder ao enunciador: o poder de comunicar um sentimento privado.

Rosita é uma mulher que espera. À semelhança dos demais personagens de Honwana, ela está imóvel. Mas nem tanto. Tem força para dizer. Por isso, qualquer coisa de diferente acontece aqui: Rosita, se apropriando de uma língua que não parece ser sua e com a qual pena para descrever o tamanho do amor, tenta romper o silêncio que atravessa a obra Nós matamos o Cão Tinhoso!, silêncio que só as balas das espingardas conseguem quebrar, e que o título vem, ao modo de um tiro, denunciar, acusar, confessar. 


\section{Referências Bibliográficas}

CRAVEIRINHA, José. “Mamana Fanisse”. In: Hamina e outros contos. 2. ed. Lisboa: Caminho, 1997, p. 69-79.

DIAS, João. Godido e outros contos. Reprodução da 1 ed. Lisboa: Casa dos Estudantes do Império/Seção de Moçambique, 1952. Lisboa: Semanário Sol, Encarte, 2014.

HONWANA, Luís Bernardo. "Rosita, até morrer”. In: Vértice, v. XXXI, n. 3312-32, ago-set, 1971. Coimbra, Portugal.

HONWANA, Luís Bernardo. Nós matamos o cão tinhoso!. 1 ed. Série Autores Africanos-4. São Paulo: Ática, 1980.

HONWANA, Luís Bernardo. Nós matamos o Cão Tinhoso! Série Vozes da África. São Paulo: Kapulana, 2017. 